\title{
Kelarutan Senyawa Fenolik dan Aktivitas Antioksidan Daun Kelor (Moringa oleifera) di Dalam Rumen Secara In Vitro
}

\section{In Vitro Rumen Degradability of Phenolic Compound and Antioxidant Activity of Moringa oleifera Leaf}

\author{
Badriyah", J. Achmadi dan L. K. Nuswantara \\ Fakultas Peternakan dan Pertanian, Universitas Diponegoro, Semarang, 50275 \\ *E-mail: badriyahkala@gmail.com \\ (Diterima: 18 Juli 2017; Disetujui: 13 September 2017)
}

\begin{abstract}
ABSTRAK
Penelitian bertujuan untuk mengkaji degradabilitas polifenol dan aktivitas antioksidan daun kelor (Moringa oleifera) di dalam rumen secara in vitro. Daun kelor dan lamtoro (Leucaena leucocephala, sebagai pembanding) diinkubasikan dalam cairan rumen kambing selama 48 jam secara in vitro. Degradabilitas bahan kering, senyawa fenolik dan aktivitas antioksidan pada daun kelor dan lamtoro dibandingkan dengan uji T. Degradabilitas bahan kering daun kelor lebih tinggi $(\mathrm{p}<0,05)$ daripada daun lamtoro. Degradabilitas senyawa fenolik daun kelor lebih rendah $(\mathrm{P}<0,05)$ daripada daun lamtoro. Penurunan aktivitas antioksidan daun kelor lebih kecil dibandingkan daun lamtoro selama inkubasi dalam rumen. Inkubasi daun kelor dalam rumen dapat menurunkan ketersediaan senyawa fenolik dan aktivitas antioksidan pada daun kelor dan lamtoro.
\end{abstract}

Kata kunci: senyawa fenolik, aktivitas antioksidan, daun kelor, degradabilitas in vitro

\section{ABSTRACT}

The research was aimed to study the degradability of phenolic compounds and antioxidant activity of moringa leaves (Moringa oleifera) in the rumen in vitro. Moringa and Leucaena (Leucaena leucocephala, as a comparison) leaves were incubated in goat rumen liquid for $48 \mathrm{~h}$ in vitro. The in vitro degradabilities of dry matter, phenolic compounds and antioxidant activity in moringa leaf and lamtoro leaf were compared using the T-test. The dry matter degradability of moringa leaf was higher $(p<0.05)$ than Leucaena leaf. The phenolic compound degradability of moringa leaf was lower $(P<0.05)$ than Leucaena leaf. The decrease in antioxidant activity of moringa leaf was smaller than Leucaena leaf after incubation in the goat's rumen. The incubation of moringa and Leucaena leaves in the rumen may reduce the availability of the phenolic compound, and thus lowering their antioxidant activity.

Keywords: phenolic compound, antioxidant activity, moringa leaf, in vitro degradability

\section{PENDAHULUAN}

Bahan pakan yang mengandung senyawa metabolit sekunder tertentu memiliki potensi sebagai antioksidan dapat mencegah reaksi oksidasi untuk menghambat radikal bebas yang menyebabkan rusaknya sel-sel di dalam tubuh (Rohyani et al., 2015), sehingga pakan yang mengandung antioksidan tinggi dapat digunakan sebagai pakan alternatif, salah satunya yaitu tanaman Moringa oleifera atau kelor. Tanaman kelor memiliki senyawa utama yaitu senyawa flavonoid yang memiliki sifat sebagai antioksidan (Ikalinus et al., 2015). Selain mengandung flavonoid, tanaman kelor juga mengandung asam lemak tak jenuh seperti linoleat (omega 6) dan alfalinolenat (omega 3). Tanaman kelor tinggi akan kandungan nutrisi berupa protein, $\beta$-karoten, vitamin $\mathrm{C}$, mineral terutama zat besi dan kalsium (Palupi et al., 2015).

Antioksidan merupakan senyawa yang digunakan untuk menghambat radikal bebas di dalam tubuh. Adanya antioksidan 
Tabel 1. Formulasi ransum kambing fistula.

\begin{tabular}{lrrrrr}
\hline Bahan Pakan & Formula & PK bahan & PK pakan & TDN bahan & TDN pakan \\
\hline Gaplek (\%) & 1,10 & 5,33 & 0,06 & 74,58 & 0,82 \\
Tetes (\%) & 1,00 & 0,66 & 0,01 & 75,01 & 0,75 \\
Bungkil kedelai (\%) & 17,00 & 35,97 & 6,11 & 81,10 & 13,79 \\
Bekatul (\%) & 10,70 & 9,70 & 1,04 & 67,48 & 7,22 \\
Mineral (\%) & 0,20 & 0,00 & 0,00 & 0,00 & 0,00 \\
Rmput gajah (\%) & 70,00 & 7,02 & 4,91 & 54,85 & 38,39 \\
\hline Jumlah & 100,00 & & 12,13 & & 60,97 \\
\hline
\end{tabular}

yang mampu mencegah adanya radikal bebas maka diharapkan sistem pertahanan tubuh ternak semakin baik. Senyawa fenolik pada daun kelor bekerja secara fagositosis untuk menghancurkan bakteri patogen yang masuk, sehingga dengan tidak adanya bakteri yang masuk menyebabkan tubuh tidak mengeluarkan antioksidan sebagai antibodi untuk pertahanan terhadap serangan bakteri (Toripah et al., 2014).

Antioksidan merupakan senyawa metabolit sekunder yang digunakan untuk mencegah radikal bebas. Semakin tinggi aktivitas antioksidan, semakin banyak radikal bebas yang dicegah. Semakin tinggi total fenol pada suatu bahan pakan berarti akan menunjukkan tingginya aktivitas antioksidan (Sandrasari, 2008). Fenol merupakan senyawa induk dari fenolik yang banyak terdapat pada tumbuhan.

Aktivitas antioksidan daun kelor telah banyak diteliti pada manusia dan ternak monogastrik. Sebagai upaya untuk memaksimalkan manfaat tanaman daun kelor untuk ruminansia, perlu adanya penelitian untuk menguji perubahan ketersediaan senyawa fenolik dan aktivitas antioksidan daun kelor pasca pencernaan ruminal. (Toripah et al., 2014) menyatakan inhibition concentration $\left(\mathrm{IC}_{50}\right)$ merupakan suatu zat antioksidan yang dapat memberikan persen penghambatan $50 \%$ atau bilangan yang menunjukkan konsentrasi ekstrak (ppm) yang mampu menghambat proses oksidasi sebesar $50 \%$.

\section{METODE}

Penelitian menggunakan materi antara lain daun kelor yang berasal dari daerah Kabupaten Jepara serta daun lamtoro (berasal dari Kebun Penelitian Fakultas Peternakan dan Pertanian Universitas Diponegoro, Kampus Tembalang) sebagai pembanding. Cairan rumen berasal dari 2 ekor kambing berfistula. Kambing diberi pakan dengan komposisi yang ditunjukkan pada Tabel 1. Uji in vitro dilakukan dengan teknik batch culture selama 48 jam sesuai metode Tilley dan Terry (1963). Analisis senyawa fenol sesuai dengan metode Folin-Ciocalteu (Vazquez et al., 2008). Analisis antioksidan sesuai dengan metode DPPH atau 1-1-diphenyl-2-picrylhydrazyl) (Fitri et al., 2015). Pada penelitian ini, hasil uji in vitro daun kelor dibandingkan dengan daun lamtoro. Pembandingan antara degradabilitas bahan kering, kelarutan senyawa fenol dan aktivitas antioksidan pada kelor dan lamtoro dilakukan uji $\mathrm{T}$ dilanjutkan dengan analisis deskriptif.

\section{HASIL DAN PEMBAHASAN}

\section{Degradabilitas Bahan Kering secara In Vitro}

Hasil dari penelitian degradabilitas bahan kering secara in vitro ditunjukkan pada Tabel 2. Persentase degradabilitas bahan kering pada kelor lebih tinggi daripada lamtoro yaitu $60,61 \%$ sedangkan lamtoro $43,39 \%$. Hasil tersebut dapat ditunjukkan dari kandungan NDF kelor yang lebih rendah sebesar $22,75 \%$ sedangkan lamtoro $28,19 \%$, sehingga mudah 
Tabel 2. Persentase degradabilitas bahan kering pada kelor dan lamtoro.

\begin{tabular}{lccc}
\hline Sampel & Degradabilitas BK (\%) & Total Fenol (\%) & Aktivitas Antioksidan (ppm) \\
\hline Kelor & $60,61^{\mathrm{a}}$ & 0,94 & 283,19 \\
Lamtoro & $47,39^{\mathrm{b}}$ & 1,99 & 43,65 \\
\hline
\end{tabular}

Keterangan: Superskrip a,b yang berbeda pada kolom yang sama menunjukkan perbedaan nyata $(p<0,05)$.

dicerna dalam saluran pencernaan ternak. Ghunu dan Ana (2006) menyatakan NDF merupakan komponen dinding sel yang sulit dicerna karena mengandung serat yang lebih tinggi dari isi sel.

Selain NDF, kandungan ADF juga mempengaruhi degradabilitas bahan kering. Kandungan ADF daun kelor lebih rendah sebesar $15,57 \%$ sedangkan lamtoro $23,38 \%$. ADF terdapat pada dinding sel yang terdiri dari selulosa dan lignin dimana selulosa dan lignin merupakan komponen dari ADF yang sulit dicerna daripada hemiselulosa. Van Soest (1984) menyatakan bahwa kandungan dinding sel suatu bahan pakan yang rendah akan meningkatkan laju degradasinya. Qadriyanti (2014) menambahkan semakin rendah kandungan ADF dan NDF maka akan semakin baik karena kandungan seratnya lebih rendah sehingga lebih mudah dicerna oleh ternak.

Degradabilitasbahankeringdipengaruhi oleh pencernaan fermentatif karbohidrat pakan dalam rumen menjadi VFA. Kadar VFA daun kelor lebih tinggi sebesar 126,67 $\mathrm{mM}$ daripada lamtoro yaitu $93,33 \mathrm{mM}$. VFA rumen akan meningkatkan aktivitas mikrobia rumen sebagai sumber energi. Semakin tinggi degradabilitas bahan kering maka kadar VFA rumen yang dihasilkan akan semakin tinggi. Gusasi (2014) menyatakan proses fermentasi di rumen dapat meningkatkan laju degradasi pakan yang dipengaruhi oleh tingginya konsentrasi VFA. Tingginya konsentrasi VFA akan meningkatkan aktivitas mikrobia di dalam rumen. Kurniawati (2004) menyatakan, tingginya kandungan karbohidrat dapat meningkatkan laju pertumbuhan mikrobia rumen dan laju degradasi di dalam rumen.

Konsentrasi $\mathrm{NH}_{3}$ rumen juga mendukung tingkat degradabilitas bahan kering. Konsentrasi NH3 rumen pada kelor lebih tinggi sebesar $39,765 \mathrm{mg} / 100 \mathrm{ml}$ sedangkan lamtoro $39,033 \mathrm{mg} / 100 \mathrm{ml}$. Hasil tersebut dapat menunjukkan bahwa degradabilitas bahan kering pada kelor lebih tinggi dari lamtoro karena konsentrasi $\mathrm{NH}_{3}$ yang tinggi akan meningkatkan laju degradasi protein di dalam rumen. Saqifah et al. (2010) menyatakan, degradasi bahan kering pakan dapat dipengaruhi oleh produksi amonia di dalam rumen.

\section{Kelarutan Senyawa Fenol di dalam Rumen}

Hasil kelarutan fenol secara in vitro selama 48 jam diketahui bahwa pada kelor dan lamtoro berbeda nyata $(\mathrm{p}<0,05)$ ditunjukkan pada Tabel 3. Kelarutan senyawa fenol pada kelor lebih rendah yaitu $80,50 \%$ sedangkan lamtoro lebih tinggi sebesar 94,97\%. Hasil tersebut diduga disebabkan oleh kandungan fenol yang terdapat pada lamtoro juga tinggi yaitu $1,99 \%$ sedangkan kelor $0,94 \%$. Semakin tinggi kandungan fenol pada tanaman maka dapat menunjukkan bahwa kelarutan senyawa fenol juga tinggi. Senyawa fenol yang tinggi dapat menunjukkan bahwa terjadi aktivitas antioksidan yang kuat. Toripah et al. (2014) menyatakan apabila kandungan fenol di dalam sampel tinggi akan menunjukkan aktivitas antioksidan yang berlangsung juga tinggi.

Fenol merupakan senyawa yang hanya memiliki satu gugus hidroksil pada penyusunnya. Fenol termasuk senyawa metabolit sekunder yang merupakan turunan dari pentosa fosfat, shikimate serta fenilpropanoid yang terdapat pada tanaman (Randhir et al., 2004). Fenol dan aktivitas antioksidan saling berhubungan karena fenol memiliki peran utama dalam jalannya aktivitas antioksidan. Fitri et al. (2008) menyatakan fenol berperan sebagai kontributor utama terhadap aktivitas antioksidan pada kelor. 
Tabel 3. Persentase kelarutan fenol dan aktivitas antioksidan pada kelor dan lamtoro

\begin{tabular}{lccc}
\hline \multirow{2}{*}{ Pakan } & Kelarutan fenol secara in & \multicolumn{2}{c}{ Aktivitas Antioksidan } \\
\cline { 3 - 4 } & vitro (\%) & Kelor (ppm) & Lamtoro (ppm) \\
\hline Kelor & $80,50^{\mathrm{b}}$ & 283,19 & 1485,24 \\
Lamtoro & $94,97^{\mathrm{a}}$ & 43,65 & 1193,43 \\
\hline
\end{tabular}

Keterangan: Superskrip a,b yang berbeda pada kolom yang sama menunjukkan perbedaan nyata $(p<0,05)$.

Fenol pada kelor dapat larut setelah inkubasi dalam rumen diduga dapat dimanfaatkan oleh mikrobia rumen. Fenol merupakan komponen dari karbohidrat struktural yang lebih sulit dicerna karena mengandung serat yang tinggi. Semakin tinggi fenol yang dapat larut diduga semakin tinggi serat dalam tanaman tersebut. Tingginya kandungan serat dapat ditunjukkan dari kandungan ADF dan NDF. Kandungan ADF dan NDF pada lamtoro lebih tinggi dari kelor menunjukkan kelarutan fenol pada lamtoro juga tinggi. Fenol dapat terlarut diduga karena terdapat mikrobia yang bekerja dalam rumen sehingga fenol pada pakan dapat terlarut dengan bantuan enzim. Cao et al. (1997) menyatakan ikatan fenol dapat lepas karena disebabkan oleh asam, alkali dan perlakuan enzimatis dari pakan.

\section{Aktivitas Antioksidan}

Hasil aktivitas antioksidan pada kelor dan lamtoro berbeda tidak nyata $(\mathrm{p}>0,05)$ ditunjukkan pada Tabel 3. Aktivitas antioksidan ditentukan dengan nilai IC50 yang dihitung berdasarkan persamaan regresi. Zuhra et al. (2008) menyatakan suatu senyawa dapat dikatakan sebagai antioksidan kuat jika IC50 bernilai $50-100$ ppm, sedang jika bernilai 100 - 150 ppm dan lemah jika bernilai $151-200 \mathrm{ppm}$. Semakin rendah nilai $\mathrm{IC}_{50}$ yang dihasilkan maka aktivitas antioksidannya akan semakin kuat. Aktivitas antioksidan pada daun kelor diperoleh hasil sebesar 283,19 ppm, setelah inkubasi dalam cairan rumen aktivitas antioksidan menjadi 1485,24 ppm pada residu. Pada lamtoro diperoleh hasil sebesar 43,65 ppm pada daun, dan setelah inkubasi dalam cairan rumen menjadi 1193,43 ppm pada residu. Hasil dari $\mathrm{IC}_{50}$ tersebut menunjukkan bahwa setelah inkubasi dalam cairan rumen, aktivitas antioksidan mengalami perubahan sehingga diduga dapat dimanfaatkan oleh ternak. Hasil perubahan dapat dilihat dari aktivitas antioksidan kelor yang terdapat pada daun kemudian menjadi residu.

Antioksidan merupakan substansi nutrisi maupun non-nutrisi yang terkandung dalam bahan pangan yang mampu mencegah atau menghambat terjadinya kerusakan oksidatif dalam tubuh (Winarsi, 2007). IC $_{50}$ dapat menggambarkan bahwa kemampuan ekstrak metanol dalam menghambat radikal bebas di dalam rumen sebesar $50 \%$. Daun dapat dikatakan sebagai ekstrak kasar yang diduga memiliki kandungan senyawa lain yang ikut terekstrak dalam pelarut yang menyebabkan meningkatnya nilai rendemen ekstrak sehingga memiliki aktivitas antioksidan yang lebih tinggi daripada supernatan dan residu setelah in vitro. Ria (2011) menyatakan, ekstrak kasar masih mengandung senyawa lain yang bukan merupakan senyawa antioksidan yang ikut larut selama proses ekstraksi sehingga dapat meningkatkan nilai rendemen ekstrak yang diduga memiliki aktivitas antioksidan yang lebih tinggi. Tinggi rendahnya aktivitas antioksidan dan fenol dapat disebabkan oleh beberapa faktor antara lain kemampuan dalam menyeimbangkan radikal bebas agar tidak terjadi kerusakan sel yang berlebih. Cao et al. (1997) menyatakan, tingginya aktivitas antioksidan dan polifenol dapat terjadi karena faktor dari sifat redoks seperti penerapan maupun kemampuan menetralkan radikal bebas.

\section{KESIMPULAN}

Aktivitas antioksidan daun kelor menurun setelah inkubasi di rumen seiring 
dengan menurunnya konsentrasi senyawa fenolik yang diduga dapat dimanfaatkan oleh mikrobia rumen.

\section{DAFTAR PUSTAKA}

Cao, G. E., Sofic dan R. L. Prior. 1997. Antioxidant and prooxidant behavior of flavonoid structure activity relationships. Free Radical Biologi \& Medicine. USA. 22 ( 5 ) : $749-760$.

Fitri, A. T., Toharmat, D. A. Astuti dan H. Tamura. 2015. The potential use of secondary metabolites in moringa oleifera as an antioxidant source. Media Peternakan. Bogor. 38 ( 3 ) : 169 - 175.

Ghunu, S. dan A. T. Ana. 2006. Perubahan komponen serat kume (Sorghum plumosum var. Timorense) hasil biokonveksi jamur tiram putih (Pleurotus ostreatus) akibat kadar air substrat dan dosis inokulum yang berbeda. Jurnal Ilmu Ternak. Bandung. $6(2): 81-86$.

Gusasi, A. 2014. Nilai PH, produksi gas, konsentrasi amonia dan VFA sistem rumen in vitro ransum lengkap berbahan jerami padi, daun gamal dan urea mineral molases liquid. Fakultas Peternakan. Universitas Hasanudin. Makassar. (Skripsi).

Ikalinus, R., K. W. Sri dan N. L. E. Setiasih. 2015. Skrining fitokimia ekstrak etanol kulit batang kelor (Moringa oleifera). Indonesia Medicus Veterinus. Bali. 4 ( $1)$ ) $71-79$.

Kurniawati, A. 2004. Pertumbuhan mikroba rumen dan efisiensi pemanfaatan nitrogen pada silase red clover (Trifolium pratense cv, Sabatron). Risalah Seminar Ilmiah dan Pengembangan Aplikasi Isotop dan Radiasi. Jakarta.

Palupi, H., T. D. Agung, R. Muzaki dan B. Ratna. 2015. Pengaruh penambahan ekstrak daun kelor terhadap kualitas yoghurt. Jurnal Teknologi Pangan. Pasuruan. 6 ( 2 ) : $59-66$.
Qadriyanti, D. 2014. Karakteristik degradasi ADF dan NDF tiga jenis pakan yang disuplementasi daun gamal dalam rumen kambing secara in vitro. Fakultas Peternakan. Universitas Hasanudin. Makassar. (Skripsi).

Randhir, R., Y. T. Lin and K. Shetty. 2004. Phenolics, their anti $\neg$ oxidant and antimicrobial activity in dark germinated fen $\neg$ ugreek sprouts in response to peptide and phytochemical elicitors. Asia Pac. J. Clin. Nutr. 13 : $295-307$.

Ria, O. R. 2011. Kandungan fenol, komponen fitokimia dan aktivitas antioksidan Lamun Enhalus acoroides. Fakultas Perikanan dan Ilmu Kelautan. Institut Pertanian Bogor. Bogor. (Skripsi).

Rohyani, I., S. A. Evy dan Suripto. 2015. Kandungan fitokimia beberapa jenis tumbuhan lokal yang sering dimanfaatkan sebagai bahan baku obat di Pulau Lombok. Prosiding Seminar Nasional Masyarakat Biodiversity Indonesia. Nusa Tenggara. 1 ( 2 ) : 388 -391 .

Sandrasari, D. A. 2008. Kapasitas antioksidan dan hubungan nilai total fenol ekstrak sayuran Indigenous. Sekolah Pascasarjana. Institut Pertanian Bogor. (Tesis).

Saqifah, N., E. Purbowati dan E. Rianto. 2010. Pengaruh Ampas Teh dalam Pakan Konsentrat terhadap Konsentrasi VFA dan NH3 Cairan Rumen untuk Mendukung Pertumbuhan Sapi Peranakan Ongole. Paper presented at the Seminar Nasional Teknologi Peternakan dan Veteriner.

Tilley, J. M. A. and R. A.Terry. 1963. A two stage technique for the in vitro digestion of forage. J. British Grassland Soc. 18 : $104-111$.

Toripah, S., S. A. Jemmy dan W. Frenly. 2014. Aktivitas antioksidan dan kandungan total fenolik ekstrak daun kelor (Moringa Oleifera Lam.). Jurnal Ilmiah 
Farmasi. Manado. 3 ( 4 ) : $37-43$.

Van Soest, P. J. 1984. Nutritional Ecology of the Ruminant: Second Edition. Cornell University. New York.

Vázquez, G., E. Fontenla, J. Santos, M. S. Freire, J. González-Álvarez and G. Antorrena. 2008. Antioxidant activity and phenolic content of chestnut (Castanea sativa) shell and eucalyptus
(Eucalyptus globulus) bark extracts. Industrial Crops and Products. 28 ( 3 ) : 279 - 285.

Winarsi, H. 2007. Antioksidan Alami dan Radikal Bebas. Kanisius. Yogyakarta.

Zuhra, C. F., T. Br, Juliati dan S. Herlince. 2008. Aktivitas antioksidan senyawa flavonoid dari daun katuk. Jurnal Biologi Sumatera. Sumatera. 